\title{
Kunstniku Kalevipoeg: eepose ja müüdi taasesitus Kristjan Rauast Gunnar Neemeni
}

Kärt Summatavet

doi:10.7592/PS/28-1summatavet

Teesid: Artikkel käsitleb müüdi ja eepose kujutamisega seotud kunstiteoseid, keskendudes "Kalevipoja" väljaannetele. Vaatluse all on kolm meetodit, mida kunstnikud on selle eepose raamatugraafika kujundamisel ning müüdi tegelaste ja sündmuste kujutamisel kasutanud. Eepos ja müüt on vaadeldavad inimese kujutlusvõime tulemustena, mille taasesitamisel põimuvad kunstnike teostes rahvalooming ja professionaalne kunst, üldised ja isiklikud ning igavikulised ja üldinimlikud teemad. Vaatluse all on ka kunstniku roll müüdi taasesitajana ning rahvaloomingu interpreteerimisel ilmnevad müüdi eetilise ja esteetilise tõlgendamise küsimused. Eepose kujutamisega seoses leiab käsitlemist ka kunstniku uurimistöö fenomen, mida eepose-aineliste teoste puhul alati ei pruugita väärtustada, kuid mis sellegipoolest mõjutab kunstnike loomingut.

Märksõnad: müüt, eepos, kunst, “Kalevipoeg”, loomemeetod, kujutlusvõime, inspiratsioon, müüdi taasesitus

\section{Sissejuhatuseks}

Eepos "Kalevipoeg" ning rahvapärased allikad ja muistendid, mis on ilmunud kogumikes "Kalevipoja esi-isad" (Eisen 1920), "Muistendid Kalevipojast” (Laugaste, Normann 1959) ja võrguväljaandes "Kalevipoeg" (1999), on kunstnikele omanäoliseks inspiratsiooniallikaks ja kujutlusvõimet avardavaks allikmaterjaliks, kuid loo- 
mingulise ülesandena tõsiseks väljakutseks. Kunstiteadlane Mai Levin on tabavalt märkinud, et 1935. aastal ilmunud "Kalevipoja" juubeliväljaandest on kujunenud Eesti iseseisvusaegse rahvusromantilise kunsti monument. Kuid ka Kristjan Raua loominguline lähenemine vajas aega harjumiseks. Raua arhaiseeriv, jõuliselt üldistav stiil paistis 1930. aastatel paljudele primitiivsena, mistõttu Tartu Kunsti ja Kirjanduse Klubi korraldas 1937. aastal kunstniku teoste üle "kohtu", mis pidi seda stiili laiemale publikule seletama ja õigustama (Levin 2010: 107-108). Raua loodud "monument" on nüüdseks pälvinud üldise tunnustuse, kuid seda enam tabab iga järgnevat "Kalevipoja" illustreerijat publiku kõrgendatud ja kriitiline tähelepanu. Käesolev artikkel on katse anda põgus ülevaade "Kalevipoja" eepose teemal loodud erisuguse loomesõnumi ja suunitlusega raamatugraafikast ning sealhulgas tutvustada, kuidas kunstnikud on interpreteerinud eepost ka siis, kui neil puudub otsene kokkupuude müüdi ja rahvaloominguga.

\section{Loomeprotsess ja selle kirjeldamine}

Kunstnikult oodatakse tema kujutlusvõime ja ümbritseva reaalsuse vahekordade originaalset väljendust. Kunstiteadlase Ernst H. Gombrichi sõnul vaimustab looja oma kaasaegseid tihti just sellega, mis tema teostes on traditsioonilisest erinev: "Iga kunstnik arvab olevat ületanud eelmise põlvkonna poolt saavutatu ja et tema seisukohalt on ta ise jõudnud kaugemale kui keegi teine enne teda" (Gombrich 1997: 8-9). Ta lisab, et kunstnikel on aeg-ajalt selline tunne, et nad on avastusretkel, nad tahavad vaadata maailma uudse pilguga ja heita kõrvale kõik üldtunnustatud arusaamad ja eelarvamused (Gombrich 1997: 15). Gombrich on välja toonud ka selle, et neist kategooriatest, mille üle kõrvalseisjad arutlevad, nagu näiteks ilu või väljenduslikkus, räägivad kunstnikud harva ning seda, mille üle kunstnik muret tunneb, kui ta oma töid kavandab, visandeid teeb või otsustab, kas taiest lõpetatuks pidada või mitte, on loojal raske sõnades väljendada (Gombrich1997: 32). 
Paljud uurijad on arutlenud selle üle, kas ja mil määral on võimalik kunstiprotsessi kõiki aspekte eksplitsiitselt kirjeldada või sõnastada (vt nt Polanyi 1962; Schön 1983; Nonaka et al. 2000; Biggs 2004; Scrivener 2006; Niedderer, Imani 2008) ning rõhutavad, et isiklik kogemus, mida kunstnik loomeprotsessi ajal teadlikult või teadvustamata kogeb, on tihti seotud varjatud teadmiste ja oskustega, mille sõnastamiseks puudub loojal otsene vajadus või varasem kirjeldustraditsioon.

Claude Lévi-Straussi sõnul asub kunst poolel teel teadusliku teadmise ja müütilise või maagilise mõtlemise vahel. Kunstnik sarnaneb ühtaegu teadlase ja meistrimehega: käsitöölise vahenditega valmistab ta materiaalse objekti, mis on ühtaegu ka intellektuaalne objekt (Lévi-Strauss 2001: 46). Kunstnik uurib ja mõtestab maailma oma valdkonna meetodeid rakendades ning loomeprotsess avardab looja enda kujutlusvõime piire, luues uusi elamusi ja kogemusi, mis argises tegelikkuses ei eksisteeri, ning tema teosed avaldavad mõju ka vaataja kujutlusvõimele.

Juri Lotman on kirjutises "Kunsti fenomen” märkinud, et kõiki kunstiloomingu liike võib kujutleda mõtteeksperimendi erikujudena (Lotman 2001: 173-174). Ta on seisukohal, et kunst loob põhimõtteliselt uue tegelikkusetasandi, mis erineb tegelikkusest tunduvalt suurema vabaduse poolest. Oma vabaduserohkuse tõttu teeb kunst võimalikuks niihästi keelatu kui ka võimatu ning on reaalsusele otsekui vabaduse sfääriks. Kunst loob oma maailma ning võib rikkuda muu hulgas ka tavade ja harjumuste ning koguni aja ja ruumi seadusi. Ta rõhutas, et kunsti üks geniaalseid omadusi on mõtteeksperiment, mis lubab kontrollida maailma mingite struktuuride puutumatust ning sellega määratakse ka kunsti ja tegelikkuse suhe. Kunst on tunnetusvahend ja eeskätt inimese tunnetamise vahend (Lotman 2001: 170-172).

Kogumikus "Semiosfäärist" on Lotman kirjutanud, et kunsti mõjujõud muudab kunsti ülimaks tunnetusjõuks - kõrgeimaks tipuks, kuhu inimene teda ümbritsevate maailmade varjatud saladuste valdamisel võib tõusta (Lotman 1999: 182). Samas teoses on ta esile toonud ka kunstiteose vaataja rolli ning rõhutanud, et arhailise loomingu omapära seisneb tema esitaja ja kuulaja funkt- 
sioonide jaotuses. Folkloori arhailised vormid on rituaalsed ning neil puudub passiivne auditoorium. Arhailine rituaal eeldab arhailist maailmatunnetust, mida kunstlikult taaselustada ei ole võimalik. Esitaja ja vaataja ühtesulamine eeldab kunsti ning selle tegemise ühtesulamist, keskendumist loomeprotsessile ja mitte vaid selle tulemusele. "Ajaloolisse aega" kuuluva kunsti puhul toimub jagunemine esitajateks ja auditooriumiks, mispuhul kunsti vaataja on samal ajal tegelikkuses mitte-vaataja: ta näeb, kuid ei sekku, on kohal, kuid ei tegutse ja ei osale kunstiruumis (Lotman 2001: 178-179).

Tänapäeva kunstipublik, kes ei osale teose loomisprotsessis, võib jäädagi teadmatusse, milliseid tunde- ja mõttetasandeid looja oma teosega puudutab. Argisel tasandil loodud teoseid võib igaüks oma kogemuse alusel isikupäraselt interpreteerida, neile tähendusi luua ja tuttavana tunduvaid seiku omal kombel taasesitada, kuid müütilise või müstilise kogemuse mõistmiseks vajab vaataja teadmisi ja kogemusi, mis kuuluvad tunnetusvälja, mille kunstiväline kirjeldamine on raske või isegi võimatu. Kunstnik võib vaataja abistamiseks paljastada teatud võtmesõnad või selgitada, mida ta tundis või mõtles ning sellega vähendada kunstiruumi "varjatud saladuse" astet, kuid vaataja loomeprotsessiga ühtesulamise võimalused jäävad siiski teatud astmeni piiratuks.

Vaatajal on kunstnikust meistrimehe ja käsitöölise tunnetustasandiga liiga vähe ühiseid kogemusi, sest teose looja varjatud oskuste uurimisel ja kirjeldamisel on lühike ajalugu ning praktikud-kunstnikud osalevad selles uurimisprotsessis lühikest aega. Kunstniku peamised töövahendid on kujutlusvõime, emotsioon, tunne ja isiklik kogemus, aga ka treenitud oskused, mille kõrgtasandil omandamine on eeltingimuseks professionaalsele kunstiloomingule. Autori mõtete ja tunnete edastamine toimub kunstiruumiga seotud isikupärases väljenduskeeles, loomingulist "käekirja" treenitakse kunstikõrghariduse algastmest alates ning see on pikaajaline ja sõnadega raskesti kirjeldatav protsess (vt nt Summatavet 2010a: 22). Eesti professionaalse kunstihariduse kõigil astmetel toimub teatud süsteemne õppeülesannete järjestikune omandamine, mille käigus ópitakse oskusi ümbritseva maailma 
uurimiseks, mõtestamiseks, kujutamiseks, interpreteerimiseks ning loometöö vahendite-oskuste abil tõlkimiseks, esitamiseks ja uuendamiseks.

\section{Müiut ja selle kujutamine}

Sünteesides eri allikaid ja uurides kunstiloomingu kaudu teadusliku teadmise ning müütilise või maagilise mõtlemise vahelisi seoseid, võib kunstnikupositsioonilt öelda, et müüt on iidne lugu, millele kuju andmiseks peab kunstnik müüditegelikkusest usaldusväärse teose sünnitama. Müüdi kujutamine ei ole kerge ülesanne, sest üleloomulik muistne lugu on mitmekihiline, suure tähendusväljaga ning inimeste kujutlusvõime poolt korrastatud avar muinasmaastik, mida pole võimalik argieluks taandada (vt Summatavet 2010a, 2010b). Selleks, et kunsti väljendusvahendite abil müüdi igavikulisi ja üldinimlikke teemasid nähtavaks kujustada, tuleb kunstnikul õppida tundma rahvaloomingut, häälestuda loomeprotsessi kaudu arhailisele maailmatunnetusele ning uurida loomeprotsessi kaudu poeetilises sõnas väljendatud arhailisi kujutlusi.

Matthias Johann Eisen on "Eesti mütoloogia" (1919) sissejuhatuses kirjutanud, et sõna kitsamas mõttes tähendab müüt iseäralikku ennemuistset juttu, kuid laiemas mõttes tavalistest inimestest kõrgemal seisvate, muistsete olevuste tegevuse kirjeldust. Esivanemad punusid oma teadmise, ettekujutuse kõrgematest olevustest müütidesse ning püüdsid neile n-ö käega katsutava ja silmaga nähtava kuju anda (Eisen 1995: 4). Erinevate käsitluste hulgas on müüdi mitmetähenduslikkuse tagamaid seostatud ka rahvausundi, suulise ja ainelise rahvaloomingu ning šamanismiga (vt n Eliade 1974; Lang 1999; Siikala 2002; Hoppál 2008). Seppo Knuuttila märgib artiklis "Nähtud ja kujutatud müüdid", et müütide kaudu esilekerkivad küsimused algupärast, piiridest, saladustest ja tulevikust vaevavad inimesi tänapäevani. Kuigi müütide tõlgendused ja rakendused muutuvad aja jooksul, on nende ülesehitus ja nende üle toimuvad arutlustavad oma aegluselt üleajaloolised. Müüte 
korratakse, tõlgendatakse ja tehakse nähtavaks kõigil kunstialadel (Knuuttila 2010: 9).

Loomisprotsess, mille käigus loob kunstnik müüdile nähtava kuju ja esituse, eeldab süvenemist suulises pärimuses talletatud lugude allikatesse. Kunstniku loomeprotsessi eesmärk võib olla müüditeemade illustreerimine, kuid ka kunsti kaudu osalemine arhailise kogukonna sees jagatud kogemuses ning elamuses. Suuline rahvalooming on huvitav inspiratsiooniallikas, mille interpreteerimisel ja illustreerimisel lähtub kunstnik teatud oskustest, kogemustest ja kujutlusvõimest.

Hasso Krull kirjutab oma essees "Loomise mõnu ja kiri", et suuline kirjandus, laul ja laulmine on rituaalne toiming, millega keele ja maailma kosmiline ühtsus täide viiakse. Iga laulmine on alati tagasitulek ja uus algus. Laulmine tähendab rituaalset tagasitulekut, korraga kõige kokkukogumist ja vallapäästmist. Sellepärast on laulikul kosmogooniliselt keskne asend ja talle omistatakse erilist väge. See maailm on loodud laulja ja tema kogukonna jaoks ning ei ole enam võõras, vaid kodune ja omane (Krull 2006: 10).

Nii nagu muistne laulik, kuulub ka müüti ja eepost mõtestav ning kujutav kunstnik muistse loo taasesitajana arhailise müütilise maastiku keskpunkti. Kunstnikul on müüdi taasesitajana alati teatud vastutus ja roll, sest tahes või tahtmata osaleb ta oma kujutlusvõime abil üldinimlikes kogemustes, mida on põlvest põlve talletatud ning edasi antud suulise ja ainelise rahvaloomingu kaudu. Kunstniku loojavabadusega kaasnev ülesanne on sel puhul analüüsida ka loomisprotsessi eetilisi ja esteetilisi eesmärke, et teadlikult või ka intuitiivselt valida sobiv esitusviis ning loominguline lahendus, millel on sihtrühm ja sõnum.

Ülo Valk kirjutab 2011. aastal ilmunud "Kalevipoja” väljaandes, et "Kalevipoja" lauliku esituses hakkab sõnamaagiline laulmine toimima, äratades ellu poeetilises sõnas varjatud müüdilise alge, mis lubab kõnelda tõtt kõige oleva päritolust ning jutustada sellist loomislugu, mis käivitab loomisprotsessi. "Kalevipojas" võtab kuju grandioosne vaatepilt kaugest ja eriskummalisest maailmast, mis on rohmakas, ürgne ja lummav (Valk 2011: 532). Kunstniku loomisprotsessi võtmeküsimuseks ongi sõnumi leidmine, mis ins- 
pireerib teda teost looma ning valima sobivad meetodid ja võtted, et seda kauget ja eriskummalist maailma, "grandioosset vaatepilti" tõepäraselt või kunstnikupositsioonilt ja oma vaatenurgast esitada.

Selleks, et taasesitada või interpreteerida müüditegelikkust, püüab kunstnik müüdi teemasid mõtestatult ja elamuslikult isikliku ruumi - keha ja kujutlusvõime - kaudu kogeda, müüdis empaatiliselt osaleda ja tegelaskujudega samastuda, et loomeprotsessi ajal tekkivaid elamusi ja sõnumeid kunsti vahendite abil nähtavasse keelde tõlkida. Kui kunstnik õpib usaldama pärimust, märkab ja kogeb ta rahvaloomingu esitamisel tekkivaid iidseid rütme, kujundeid, maastikke, värve ning tunneb ja mõtestab neid salapäraseid kosmogoonilisi kogemusi, mis mõjutavad loomisprotsessi ajal tema teadlikke ja intuitiivseid loomingulisi otsuseid.

Kalevipoja-aineliste teoste puhul on kunstnikud lähtunud nii professionaalse kunsti kui rahvapärase loometöö praktikast, kuid ka vastavale ajastule omastest teadus- või kunstikäsitlustest. Nad on kujutanud müüditegelasi ja erilisi sündmusi nii lugemiskogemusele kui ka eepose tõlgendustele toetudes. Mõnede pärimust laiemalt mõtestavate kunstnike tööprotsessi võib teatud juhtudel võrrelda ka rahvaloomingu autorite loomeprotsessiga, sest kunsti kaudu arhailisi kujutelmi läbi elades on loojad püüdnud edastada üldinimlikke kogemuslikke ja elamuslikke teadmisi, mida argises kõnekeeles on raske väljendada.

Müüt kui arhailiste kujutluspiltide kogum, mida antakse edasi kogukonna sees jagatud vaimsete kogemuste ja elamuste mõtestatud kujutluspiltide kaudu, kogetakse ja mõtestatakse professionaalse kunstniku poolt uuesti läbi, esitatakse uuel kujul. Müüdi ja eepose alastest teadmistest ning loome-eesmärkidest sõltub, kuidas ja kuivõrd sügavuti autor süveneb "Kalevipoja” lugudesse ning millises loomevõtmes ta otsustab eepost kujutada. Kunstnik võib teatud piirini mõista ka kunagiste laululoojate ja müütilise loomisloo esitajate vaimusilmas sündinud kujutluspilte, mida tekst edasi annab. Ta eksperimenteerib, sünteesib ja loob neist teadetest oma struktuuri, esitades rahvaloomingu alusel sündinud kogemusi ja ettekujutusi professionaalse kunsti visuaalse kommunikatsiooni süsteemi, kujundite, märkide ja teadete keeles. 
Mõtteeksperimendid, mis on inspireeritud arhailisest maailmatunnetusest ning lähtuvad samas ka loomevabadusest, lubavad oletada, kuhu inimene teda ümbritsevate ja läbivate maailmade varjatud saladuste valdamisel võib tõusta. Müüdi taasesitajana võib tänapäeva kunstnik küll märgata ning omal kombel mõista argises ja pühas keeles esitatud pärimusdetaile, kuid erinevaid tähendusvälju loov müüdi taasesitus on alati seotud ka müüdi ja eepose käsitlustest väljaspool asuvate mõjuteguritega.

\section{Müiut ja "sotsiaalne tellimus"}

Kunstipublikul on teatud ootused, harjumused ja eelarvamused, milline võib või peab eepos-monument olema. "Kalevipoega" illustreerinud kunstnikel on vaataja ja tellija antud keeruline loomeülesanne, mis piirab loojavabadust ning on rohkemal või vähemal määral seotud üldiste huvide ja ootustega, kuid paratamatult sõltunud ka poliitilisest oludest ja ideoloogilisest survest. Kuigi artikli eesmärk on vaadelda "Kalevipoja" väljaandeid kujundanud kunstnike loomemeetodeid ning mitte analüüsida ajaloolisi või poliitilisi aspekte, on siinkohal otstarbekas esile tuua mõningaid näiteid tellijapoolsest huvist või survest, mis on mõjutanud konkreetsete väljaannete kujundusprintsiipe.

Näiteks "Kalevipoja" viienda trüki saatesõnas selgitas August Annist, et teos otsustati kirjastada n-ö esteetilise rahvaväljaandena ehk illustreerituna, sest "Ilustatud Kalevipoja" küsimus oli päevakorral juba 1911. aastast alates - rahvuskirjanduse esimene ja mõjurikkaim suurteos tuli viimaks ometi varustada väärika välimusega välismaa suurte vastavate väljaannete eeskujul (vt Annist 1936: 287, 290). Kuigi Eesti Kirjanduse Selts tellis Raualt "Kalevipoja" juubeliväljaande illustratsioonid ning lühikese ajaga valmis kunstnikul hulk töid, ei pandud kõiki uudisteoseid väljaandesse, vaid raamatu kujunduses kasutati ka vanemaid teoseid, et katta illustratsioonidega kogu eepose sündmustikku (vt nt Levin 2010: 107). 
Järgmise, 1946. aastal vahetult pärast sõda Nõukogude okupatsiooni algusperioodil ilmunud "Kalevipoja" saatesõnas märkis Oskar Urgart, et seoses väljaandega oli raskusi muu hulgas ka teose mõtte ning laadi kindlaksmääramisel ja selle õigustamisel, süüdistades 1935. aastal ilmunud "Kalevipoja" väljaandjaid katses eepost ära kasutada "agressiivsetes natsionalistlikes huvides" (Urgart 1946: 235-236). Väljaande kujundaja Paul Luhtein lahendas ülesande rahvakunsti ornamente stiliseerides, sest rahvakunsti kasutamine oli aktsepteeritud ning seega ka üks väheseid turvalisi viise, kuidas poliitilisi ja ideoloogilisi teemasid vältida. Keraamik ja kunstiteadlane Helene Kuma, kes osales Nõukogude okupatsiooni algusperioodil rahvakunsti puudutavates diskussioonides, on oma ajaloolises tagasivaates selgitanud, et situatsioonis, kus kodanliku pärandi kasutamine oli rangelt keelatud, lähtusid kunstnikud põhiliselt rahvakunstist, selle ornamentidest ja ainelise pärandi kõrval ka rahvaluulest, müütidest ja muistenditest (Kuma 2001: 27).

Kaks aastat hiljem, 1948. aastal kritiseeriti poliitilise ja ideoloogilise rünnaku käigus muu hulgas Adamson-Ericut, Paul Luhteina, Günther Reindorffi rahvusliku ornamendi liigselt loomingulises interpreteerimises ning süüdistati formalismis isegi mitmeid sõja ajal Nõukogude tagalas töötanud eesti kunstnikke (vt nt Kirme 1999: 365-420). Poliitilise ja ideoloogilise surve tingimustes ilmusid 1951. aastal Alo Hoidre, Ott Kangilaski, Richard Sagritsa, Richard Kaljo ja Edith Parise ühistööna valminud "Kalevipoja" illustratsioonid. Arvestades tollaseid teravaid ja hävitavaid diskussioone ning kunstnike vastu suunatud repressioone, on Eduard Laugaste raamatu järelsõnas 1935. aasta "Kalevipoja" kujundust nimetanud dekadentlikeks illustratsioonideks, mis moonutavad Kalevipoja kuju, tema demokraatlikku sisu ja vormi (Laugaste 1951: 344). Ta märkis, et "EK(b)P Keskkomitee VIII pleenumi otsuste täitmise tulemusena ilmub nüüd Kalevipoeg Nõukogude Eesti lugeja ette uuesti oma õigel kujul" (Laugaste 1951: 345).

Laugaste järelsõnas ilmunud kriitika põimis omavahel osavalt "Kalevipoja" nii venestamise kui ka Nõukogude võimuga, esitades tollaseid ametlikke seisukohti. Võrdlusmaterjaliks võib tema järelsõna kõrvutada ka samas ideoloogilises võtmes kirjutatud eepose 
looja eluloolise ülevaatega “Fr. R. Kreutzwald 1803-1882” (vt Sõgel et al. 1953). Kakskümmend kaks aastat hiljem, 1975. aastal ilmunud "Kalevipojas" tõstis Endel Nirk Raua Kalevipoja-ainelise loomingu aga "auväärseimale kohale", tunnustades tema aastakümneid kestnud tööd eepose ja eesti muinsuse ainestikuga ning rõhutades, et eeposel on eriline roll eri kunstialade "edasiloomingu" allikana (Nirk 1975: 273).

Kunstnikele esitatud lähteülesanne, looja roll ja positsioon "Kalevipoja" interpreteerimisel ning rahvaloominguga eksperimenteerimisel tekitab tagasivaates rea olulisi küsimusi, kuid kuna käesoleva artikli eesmärk ei ole anda hinnanguid kunstnike loomingule ega analüüsida ajaloolis-poliitilisi aspekte, siis neid siinkohal pikemalt ei käsitleta. Keskendun järgnevas konkreetsetele Kalevipoja-teemalistele teostele, kitsamalt raamatugraafikale, et tutvustada neid loomemeetodeid ja eksperimente, mida Eesti kunstnikud on "Kalevipoja" kunstilisel kujutamisel kasutanud. Kuigi kujutavas kunstis on Kalevipoja-aineliste teoste loomisel rakendatud väga erinevaid loomevõtteid, võimaldavad eelpool toodud põgusad näited mõista, millise surve või mõju all on kunstnikud "Kalevipoja" tervikteose kujundamisel töötanud ning millisel määral teinud teadlikke kompromisse isikliku loominguvabaduse ja vaataja-tellija ootuste tasakaalustamiseks.

Siinkohal on asjakohane lisada, et empiirilisele materjalile toetudes on praktikust professionaalne kunstnik-pedagoog, kes jagab "Kalevipoja" illustreerijaga sama kultuuri- ja haridustausta või on omandanud teatud üldise erialase "kirjaoskuse" ja "lugemisoskuse", suuteline vaatajana selgelt eristama "Kalevipoja" kunstnike loomemeetodeid, mida looja iga konkreetse teose puhul on rakendanud. Kunstipraktikud, kes jagavad sarnaseid teadmisi, oskusi ja kunstiprotsessi kogemust, võivad selle alusel teosesse süvenedes ja temaatilist või ajaloolist konteksti piisavalt teades märgata teose looja loomeprotsessi või -eksperimendi nüansse. Kunstnikust vaataja süvenemise astmest sõltub, millisel tasemel toimub ühtesulamine ning millisel eesmärgil soovitakse vaadeldavaid loomeaspekte kirjeldada. 
Isiklikele kogemuslikele teadmistele ja oskustele ning erialastele diskussioonidele tuginedes võib "Kalevipoja" väljaannetele loodud teoste puhul välja tuua vähemalt kolm loomemeetodit, mis erinevad üksteisest nii inspiratsiooniallika kesksete rõhuasetuste valiku kui ka loomesõnumi poolest. Käsitlen ka juhtumeid, kui kunstniku algne idee ei pääse mõjule, sest väljaandja-tellija muudab autori loomesõnumit oluliselt.

\section{Esimene meetod: illustratsioon ja stilisatsioon}

Esimene meetod, mida kunstnikud "Kalevipoja" väljaannetes on kasutanud, on eepose illustreerimine ja stiliseerimine. Illustratsioon on teksti selgitav, täiendav või kaunistav pilt (ENE 3: 567) ning stilisatsioon tegelikkuse vormide ühtlustamine, skemaatiline kujutusviis, mis on omane dekoratiivkunstile, sh ornamentikale (EE 8: 653).

Stilisatsiooni ja ornamentikaõpetust on eesti professionaalses kunstikõrghariduses õpetatud juba selle algusaastatest alates (vt nt Raunam 1964: 20-21), sest 1914. aastal loodud joonistuskursustest välja kasvanud Tallinna Kunstitööstuskoolis (hiljem Riigi Kunsttööstuskool, praegu Eesti Kunstiakadeemia) töötasid õppejõud, kes olid hariduse omandanud Peterburi Parun von Stieglitzi Tehnilise Joonistamise Keskõppeasutuses (EE 8: 652). Peterburi kooli eeskujul kuulusid Kunsttööstuskooli õppekavadesse mitmesugused kompositsiooni ja stilisatsiooni õppeülesanded, mille käigus õpiti stiliseerima ka rahvakunsti ornamente (vt nt Päts 1928; Kalm 2010: 593). Rahvakunsti stiliseerimine ja pärimuse illustreerimine võimendus õppekavades Nõukogude perioodil, kuid mitmed stilisatsiooniülesanded on tarbekunsti erialadel osaliselt säilinud praeguseni. Pärast II maailmasõda loodud "Kalevipoja" illustratsioonide ja stilisatsioonide autorite hulgas on mitmeid kunstipedagooge, kes on väljaande kujundamisel lähtunud nii eepose tekstist kui ka ainelise rahvaloomingu kunstilisest interpreteerimisest.

Paul Luhtein on 1946. aastal ilmunud "Kalevipojale" loonud vaid ühe dekoratiivse figuraalse kompositsiooni, milles üksik 
muistne sõdalane võitleb raudrüüs rüütlitega. Autor annab teosega vihje sõjajärgsele perioodile omases poliitiliselt korrektses võtmes, tähistades üksinda arvukatele vaenlastele vastu astuva kangelase kujutamisega muistset vabadusvõitlust saksa ristirüütlite vastu. "Kalevipoja" kujunduses on kunstnik lähtunud siiski peamiselt rahvakunsti esemete ja ornamentide stiliseerimise võtetest. Eepose lugusid tähistavates päisliistudes ja vinjettides on ta osavalt komponeerinud dekoratiivseid kujunduselemente rahvaloomingus leiduvate detailide ainetel ning meisterlikult mustreid ja lugude tegelasi stiliseerides loonud anonüümseid ja lihtsustatud teksti toetavaid kaunistusi.

Evald Okas kujutas 1961. aastal ilmunud "Kalevipoja" illustratsioonides inimnäolist kangelast, kes töötab ja võitleb, puhkab ning pidutseb. Kalevipoeg, illustratsioonide keskne tegelane, on justkui üks meie hulgast, kellele pole võõrad ka inimlikud tunded ja nõrkused. Kunstnik on arhailist lugu esitanud argitegelikkuse võtmes ning müütiliste tegelaste stiliseeritud, kohati võõrapärased rõivad ning skemaatiliselt tähistatud tarbeesemed paigutavad piltidel kujutatud sündmused ja tegevused ebamäärastesse lähisajanditesse. Autor kujutas ja tähistas sündmusi, mis iidset lugu kaunistavad või ümber jutustavad, kusjuures tema eesmärk ei olnud esitada tõetruud pärimuskeskkonda või müüditegelikkust.

1961. aastal ilmunud Eno Raua "Kalevipoja" ümberjutustuse ehk nn laste-Kalevipoja illustratsioonide autor on Ants Viidalepp. Kunstnik on väljaande kujunduses eepose lugude algused tähistanud stiliseeritud figuratiivsete kompositsioonidega ning proosavormis lühendatud Kalevipoja-lugudes kirjeldatud sündmuste detailidega. Ka vahelehtedele trükitud ekspressiivsed värvilised teosed kujutavad üksikuid eepose sündmusi ja tegelasi, keda kunstnik on justkui kõrvaltvaatajana pildile fikseerinud, lihtsustanud ja mitmesuguste detailidega kaunistanud. Stiliseeritud rõivad, tarbeesemed ja keskkond on esitatud lihtsustatud märgiliste tähistustena, mis aitavad kunstnikul positsioneerida sündmusi ja tegelasi 20. sajandist kaugemasse, n-ö muistsesse aega.

1976. aastal ilmunud Eno Raua "Kalevipoja" ümberjutustuse on illustreerinud Heldur Laretei. Kunstnik kujutas Suurt Tamme, 
Kalevipoega ja sarvikuid humoorikate ning karikatuurilaadsete tegelastena toimetamas ja jõudu katsumas, mõõka proovimas või sängi veeres jooki rüüpamas. Peamiselt lastele suunatud teoses on muistne lugu esitatud lihtsustatult, skemaatiliselt ja dekoratiivselt. Ühemõttelisena esitatud pildid ei jäta ruumi vaataja kujutlusvõimele, illustreerides ja stiliseerides teksti ilma autoripoolsete loominguliste püüdlusteta rõhutada müüdi mitmetähenduslikkust.

Loomemeetod, mille puhul kunstnik keskendub peamiselt eepose illustreerimisele ja rahvaloomingu stiliseerimisele, kirjeldab "Kalevipoja" tegelasi ja sündmusi lihtsustatult, pigem üldistavas visuaalselt esitatud ümberjutustuse vormis ning illustratsioonid on lugemise abivahendid teksti ilmestamiseks ja kaunistamiseks.

\section{Teine meetod: kunstniku "käekiri" ja loomesõnum}

Teine Kalevipoja-teemalistes väljaannetes kasutatud loomemeetod lähtub kunstniku isikupärasest "käekirjast" ja loojasõnumist. Selle meetodi puhul autori kujutlusis tekkinud tunded, ideed ja loomesõnumid sünnivad küll eepose teemadest, kuid kunstnik loob oma teostes mitmetähenduslikke ja lugeja kujutlusvõimet ergutavaid uusi võimalusi, mis julgustavad vaatajat ka oma kujutlusvõime abil eeposesse süvenema. Seda meetodit on teiste hulgas kasutanud näiteks Jüri Arrak, Jaan Tammsaar ja Andres Tali.

1985. aastal ilmunud Enn Vetemaa romaanile "Kalevipoja mälestused" on Jüri Arrak loonud 1982. aastal valminud joonistused. Nendes teostes toob autor Kalevipoja loost esile oma varasemale kunstniku-käekirjale omaseid muistseid tegevusmaastikke. Arhailisena mõjuvas keskkonnas toimuvates sündmustes osalevad ebamaised ja üleloomulikud tegelased, kusjuures argiste tegevuste ja sündmustena näivatel situatsioonidel ei ole siiski mingit seost argielu tegelikkusega. Kunstnik esitab Kalevipoja loost inspireeritud elamuste ja vaimsete kogemuste põhjal loodud mõjusaid kujutluspilte, kuid annab ka vaatajale võimaluse siseneda sellele muinasmaastikule ning osaleda oma kujutlusvõimele toetudes eepose lugudes kirjeldatud sündmustes. 
1998. aastal ilmunud Eno Raua ümberjutustuse "Kalevipoeg" on kujundanud Jaan Tammsaar, kes esitab arhailist müüti loomisloo loojapositsioonilt. Muistse lauliku kombel toob kunstnik pilt pildi haaval nähtavale arhailise müütilise maastiku - ta loob kosmilise avaruse, pimeduses aimatava ning seejärel koiduvalguses nähtavaks muutuva vetevälja, mille kohale saabub kotka seljas lendav ja maastikku vaatlev kangelane. Kalevipoega tähistab ta vaid harvadel piltidel väikese ja kaugeneva kujuna, kes pigem sulandub ümbritsevasse hiiglaslikku keskkonda. Konkreetsete eepose tegelaste kujutamise asemel loob kunstnik arhailist kultuurimaastikku, millest kerkivad esile tähenduslikud detailid ja üleelusuuruses etnograafiline pärand, mis markeerivad iidset lugu ja Kalevipoja tegude tagajärgi sümbolite ja märkide keeles. Müüdi taasesitajana loob ta oma teostesse tunnet ja salapära, pühana ja samas ka ohtlikuna mõjuvat kujutlusmaastikku, kus autori isiklik elamus ja kujutlusis tekkinud kogemus põimitakse osavalt iidse looga.

"Kalevipoja" 2009. aastal ilmunud väljaande illustratsioonide ja kujunduse autor on Andres Tali. Kunstnik on raamatu ilmumise puhul öelnud, et väljaande kujundamisel oli tema eesmärk vältida väljakujunenud stampe, eeskujusid ja tuttavaid kujundeid, ning rõhutanud, et Kalevipojas on mitmeid jooni tema enda iseloomust (vt nt Sibrits 2009). Autor elab eepose tegelaste nahas isiklikult läbi "Kalevipoja" lugu, lähtudes seejuures oma kujutlusvõimest, kunstikogemusest ja loojavisioonist.

Tali arvates on Kalevipoeg argipäeva-inimene, kellel on oma elusaatus, mis on "kaunis dramaatiline oma tõusude ja langustega". Sirje Helme lisab, et tulemus on ajale vääriline, sest Tali Kalevipoeg on tänapäevane mees, kes oma eksistentsiaalsete vaevade käes piinleb ning mõtlematute tegude käes kannatab, mida eelmine Kalevipoeg kindlasti ei teinud (Tralla 2009). Tali on kujukas näide nüüdisaegsest kunstnikust, kes eepose loo kujutamisel lähtub lugemiskogemusest, omaenda vaimsetest, füüsilistest ja üldinimlikest 
läbielamistest ${ }^{1}$ ning ka tänapäeva loojaid mõjutavatest kujutava kunstiga seotud väärtushinnangutest ja tõekspidamistest.

Tali seiskohtadega sarnastele järeldustele on jõudnud ka mitmed "Kalevala" eepost kujutanud tänapäeva kunstnikud. "Uue Kalevala” 160. juubeliaasta (2009) eel kutsuti Kalevala-seura algatusel 10 Soome kujutavat kunstnikku ja heliloojat 2008. aastal omal valikul eepose runo-teemadest muusikalisi või pildilisi tõlgendusi looma. Taiteilijoiden Kalevala (Kunstnike Kalevala) projekti lähtekoht oli, et müüdid on ühel või teisel aistingulisel viisil esitatud (kõneldud, lauldud, maalitud, vormitud, tantsitud) kultuuri väljendused. Knuuttila sõnul müüdi esituse puhul ei ole küsimuseks, kas esitus on väljamõeldis või tõde, vaid milliseid mõtteid ja tundeid müüt äratab, kuidas ta mõjub, kuidas ta paigutub teiste müütiliste esituste ja kunstide ajaloosse (Knuuttila 2010: 9).

2009-2010 laienes Taiteilijoiden Kalevala projekt Soomest Granadasse (Hispaania) ja Benini (Aafrika) ning Kalevala 175. juubeliaasta tähistamiseks viisid Jyväskylä Ülikool ja Granada Ülikool läbi uurimis- ja kunstiprojekti Kalevala granaína, milles osalesid lisaks kümnele Soome kunstnikule ka 13 Hispaania kunstnikku. Annika Waenerbergi ja Manuel Vélez Cea uurimisprojekti käigus selgus, et tänapäeva kunstnikud tõlgendavad müüte tihti intuitiivselt, tundes eelkõige huvi mitte ajaloo, vaid müütide poolt äratatud isiklike kujutluspiltide ja tundepuhangute vastu (Vélez Cea, Waenerberg 2010: 5). Knuuttila sõnul põimuvad üldine ja isiklik, väline ja sisemine mütoloogia teineteisega nii, et esitustest võib eraldada müütiliste teemade personaalseid kompositsioone, milles leidub peegeldusi nii müütide maailmaajaloost kui ka kohalikest mikrokosmostest (Knuuttila 2010: 10). Kuigi Taiteilijoiden Kalevala teostes justkui polegi nähtavat ühendust Kalevala-kunsti varasema traditsiooniga, visualiseerivad need teosed igaüks omal viisil just neid "Kalevala" teemasid, mis paeluvad tänapäeva inimesi. Taiteilijoiden Kalevala on näide sellest, kuidas minevikku võib naasta ela-

1 Graafiku ja meediakunstnikuna on Tali varemgi kasutanud iseennast mitmete teose peategelase ja uurimisobjektina (vt nt "Iha ja igatsuse instrumendid - Mängi minuga” 2003, "Iha ja igatsuse instrumendid ...Sick and Tired...” 2004; “11 stilli/11 stills” 2006). 
muslikul ja sümboolsel viisil, kuid seda võib alati katsutavaks ja nähtavaks teha ka uuel viisil (Knuuttila 2010: 14).

Soome uurimis- ja kunstiprojekti tulemustele toetudes nähtub, et eelpool kirjeldatud loomemeetod võib inspireerida ka noorema põlvkonna kunstnikke, kellel pole kokkupuudet elava pärimusega ning kes soovivad pigem lõhkuda ja uuendada eepose tõlgendustraditsiooni seniseid piire, tõlgendades eepost lugemiskogemuse põhjal tänapäeva inimese isiklike elamuste, väärtushinnangute ja elukogemuse võtmes.

\section{Kolmas meetod:}

\section{loomislugu kui loomisprotsessi käivitaja}

Kolmanda loomemeetodi puhul on tähelepanu keskpunktis rahvaloomingu uurimine ning kunstniku pärimuse-alased süvendatud teadmised. Suulise ja ainelise kultuuripärandi tundmine täiendab ning mitmekesistab loovisiku teadmisi, olles loomeprotsessi käivitavaks inspiratsiooniallikaks, mida loovalt mõtestades seotakse autori isikupärase filosoofia ja poeesiaga. Selle meetodi puhul ei lähtu kunstnik teoste loomisel ainuüksi eeposest, vaid keskendub laiemalt rahvaluulele ning arhailistele kujutlus- ja loomisviisidele, mis tuuakse nähtavale "Kalevipoja" kaudu.

Selle loomemeetodi väljaarendajaid on mitmeid, kuid silmapaistvamad neist on eelkõige 20. sajandi alguses tegutsenud kunstnikud ja kunstipedagoogid Kristjan Raud ja Ants Laikmaa (vt Summatavet 2010a), hiljem ka Kaljo Põllu, kes kõik suunasid oma ópilasi elavat pärimust uurima ja välitöödel inspiratsiooni koguma (vt nt Põllu 1990, 1999; Summatavet 2010b). Siinkohal nimetagem ka Laikmaa õpilast Oskar Kallist, kelle Kalevipoja-ainelised teosed sündisid inspireerituna välitöödest Eesti külades, kuid kuna kunstnik pole eepose väljaandele terviklikku raamatukujunduse lahendust loonud, siis tema teoseid käesolevas artiklis ei käsitleta.

Võib väita, et see loomemeetod on kõige enam süvenemist ja aega nõudev, sest eeldab pikaajalist pühendumist pärimuse tee- 
madele ning süsteemset eeltööd. "Kalevipoja" illustreerijana iseloomustab seda kõige paremini Kristjan Raud. Näiteks 1936. aastal Eesti Kirjanduse Seltsi poolt välja antud "Kalevipojas” ilmusid Raua joonistused koos Hando Mugasto teostega. Väljaande puhul tuleb märkida, et Mugasto meisterlike ja trükitehniliselt kõrgekvaliteediliste puugravüüride kõrval ei pääse vahelehtedele paigutatud Raua teoste väikesemõõdulised must-valged reproduktsioonid kuidagi mõjule. Selles võib süüdistada väljaandja maitset, kujundusotsuseid ja teatud eeskujusid, sest võrdluseks võib tuua Eesti Kirjanduse Seltsi poolt 1939. aastal välja antud "Kalevala", kus Akseli Gallén-Kallela suuremõõtmeliste Kalevala-maalide must-valgete reproduktsioonide avaldamine on lahendatud samas kujundusvõttes. Mõlema kunstniku detailirohked teosed kaotavad väikeses formaadis algupärase mõju. Alles 1975. aastal välja antud "Kalevipoeg" ilmus suuremõõtmeliste Raua tööde reproduktsioonidega, mida eepose lugejal on huvitav detailselt silmitseda, teoste meeleollu sisse elada ning nende abil oma kujutlusvõimet avardada.

Raua teosed vajavad põhjalikku süvenemist, sest nende loomisele on eelnenud pikk eeltöö. Raud kogus ainelist ja suulist rahvaloomingut, aitas kirjasaatjatelt pärimust koguda ning Eesti Rahva Muuseumi vanavara kogumistoimkonna juhina innustas kunstnikke ja kunstiõpilasi külades ainelist pärandit koguma (vt nt Summatavet 2007, 2010a, 2011). Kunstnik otsis rahvaluule müütilistest teemadest eelkõige inspiratsiooni ning ei kasutanud otseseid eeskujusid või rahvakunsti tsitaate. Kunstiteoreetilistes kirjutistes võrdles ta rahvakunsti professionaalse kunstniku loomeprotsessiga ning märkis, et ühe väikese rahva luule, laulud, muistsed jutud, viisid, vanasõnad on "elu tarkuse tunnistused" ning igatsused tasakaalu, rütmi ja õnne järele (Raud 1913). Ta süvenes müüdi teemadesse, arutles rahvaloomingu rolli ja funktsiooni üle ning oli veendunud, et muinaslood peegeldavad nende loojate üldinimlikke unistusi ja vaimseid väärtusi: "Muinasjuttudes tunneme ennast kui vabad ja rõõmsad lapsed, sest leiame ennast siin imede ja harulduste keskel, kus valitseb siiski teatud kord, mille alusel võidavad õiglus, headus ja ilu. Muistsed viisid kergendavad meie südant iga 
kord kui me neid kuuleme ning need vaimustavad ja puhastavad kuulajat" (Raud 1913).

Raud rõhutas, et luulet ja laulu kuuldes ärkavad inimeses "peenemad elulised funktsioonid", sest "rahva vaimne energia", soovid, tunded, mõtted, ihad ja lootused on koondatud lauludesse: "Kui meie esivanemad laulu lõivad, olivad nad kõige hingega sääl juures. Nende elu oli loomise momentidel nende silma ees ja laul oli lahutamata sellega ühenduses. Laulik võttis nutta ja hõisata lauldes, ja iga kordaja ja kuulaja käis sarnasest tundetulest läbi." Ta kirjutas, et ka mustrid ehk "kirjad" ning rütm on harmoonia ja täiuslikkuse avaldus, mis sünnib intuitiivselt tegija südames ja tunnetes ning "rahustab" mõnutunnet, sest kaunistatud tarbeese on elu "rütmilise käigu" loomulik osa ning hea sõber ja abiline, kellega kõneldakse ning kellest lauldakse kui indiviidist (Raud 1911).

Raud juhtis tähelepanu sellele, et rahvaloomingus leiduvad teemad "lasevad midagi kõrgemat, tundmatut aimata" ning need tunded ja kogemused on pärit paremast ning täiuslikumast maailmast, kust laulikud oma loomingule inspiratsiooni ammutasid (Raud 1911). Kujutlus parema ja täiuslikuma maailma olemasolust ei lubanud tal rahvaluulet pealiskaudselt illustreerida ning ta püüdis süveneda muistsete loojate hingeellu: "Ma tahan kuju anda sellele suurele isesugusele, millega mind muinsus seob, kuid mida ma ikka vaid aiman ja mille kontuurid ei ole kindlad" (Kangro-Pool 1961: 61).

Kolmandana kirjeldatud loomemeetodi - kunstniku välitöö ning uurimis- ja loometöö mõtestatud seostamise puhul kujustab kunstnik "Kalevipoja" lugu laiemalt rahvaloomingule toetudes, taasesitab ning uuendab arhailisi kujutluspilte ning loob vaatajale võimaluse ka oma kujutlusvõimet suunata argielust kõrgematele mõtetele ning rahvaluules peituvatele üldinimlikele sihtidele, pürgimustele ja unistustele. 


\section{Eepos - vaimne sild kodumaaga}

Kolme eelpool kirjeldatud loomemeetodit analüüsides tekib küsimus, kuhu paigutuvad 2011. aastal ilmunud "Kalevipoja" väljaandes avaldatud Gunnar Neeme teosed. Pealiskaudsel vaatlusel mõjuvad need dekoratiivsete, ühemõtteliste ja naivistlike piltidena, kuid tervikteosesse süvenedes, kunstniku käsikirja ning tema erakirjavahetust uurides ilmneb, et Neeme kompositsioonid pole pelgalt eepose illustratsioonid. Neeme kujundatud "Kalevipoeg" on pigem omanäoline terviklik kunstiteos, milles põimuvad nii teine kui ka kolmas loomemeetod, moodustades teiste "Kalevipoega" kujundanud kunstnikega võrreldes hinnalise erandi.

Neeme teoste reproduktsioonidega väljaanne on ilmunud alles hiljuti ning nagu iga omanäolise ja tavatu kunstiteose puhul, vajab vaataja selle mõistmiseks ja mõtestamiseks aega, eriti kuna Austraalias elanud kunstniku teised teosed pole Eesti kunstipublikule tuntud. Artiklit koostades tuli autoril tutvuda kunstniku varasemate teoste, käsikirjade ja erakirjavahetusega. Suureks abiks kujunesid vestlused "Kalevipoja" väljaande peatoimetaja Marin Laagiga. Samuti osutusid tänuväärseks artikli toimetamisprotsessi vältel aset leidnud mõttevahetused. ${ }^{2}$

Neeme illustratsioonidega käsikirja uurides tekkis artikli autoril ka selge seos kunstniku eesti rahvaloomingu alaste teadmiste ning Austraalia põlisrahva arhailiste märgisüsteemide mentaalse müüditasandi ja maagilis-müstilise rituaalse loomingulise kunstiruumiga, mida ta oma "Kalevipojas" on vabalt ning loominguliselt omavahel seostanud ja ühendanud. Neeme läheb sellesse müüdimaailma sisse varasemate visuaalkultuuriliste tõlgenduste kaudu, mis on omakorda tõlgendused varasemast sõnalisest tõlgendusest. Sellise mitmekihilisuse tulemuseks on unenäolisus, mis oma-

2 E-kirjas küsib toimetaja Kadri Tüür, kas Neeme puhul saab ehk rääkida kolmanda loomemeetodi "meta-variandist", sest kunstnik ei saanud teha välitöid pärimusekandjate juures, kuid tegi "välitöid” varasemate tõlgenduste, reprode ja arhiivimaterjalidega ja sünteesis enda jaoks sealt üht-teist olulist (Kadri Tüüri e-kiri autorile, 03.06.2012). 
korda viitab Austraalia aborigeenide dream time-ile. ${ }^{3}$ Kuid selleks, et Neeme loomemeetodi tagamaid täpsemalt avada, on otstarbekas avaldada põgus ülevaade kunstniku erakogu käsikirjalistest materjalidest, mille on Eesti Kirjandusmuuseumile üle andnud Marin Laak.

"Kalevipoja" uue tõlkeväljaande avaldamise idee sündis kunstnikul koostööst ja loomingulisest sõprusest "Kalevipoja" tõlkija Triinu Kartusega (vt Laak 2011: 13). Mare Kõiva sõnul tutvustasid eestlased kodumaa poliitilist olukorda ja ajalugu Austraalia avalikkusele näitustel ja kirjasõnas, igal võimalusel ka massimeedia kaudu ning poliitilise lobbytöö abil (Kõiva 2010: 269), kuid Neeme arvates "on üsna loomulik ja võibolla ka inimlik, et pagulaskond kümnete aastate möödudes võõras ümbruses ja võõra mõju all on kaotanud füüsilise huvi kõige selle vastu mis kunagi oli eesti." Pikaajaline huvi vanema ajaloo, filosoofia ja võrdleva usundiloo vastu oli paguluses elava kunstniku viinud mõttele, et kuigi Eesti muinasaeg on talle alati müstilist mõju avaldanud, siis häirib teda Eesti "peaaegu tahtlik maha salgamine teiste rahvaste ajaloo kõrval. Milles eesti sulatamine ja ignoreeriv mitteeraldamine slaavi supist on niiöelda karvad turri ajanud. Olen jälle ja jälle enese haavatud uhkuse ja lohutuse otstarbel pöördunud tagasi Kalevipoja juurde" (G. Neeme erakogu: Kp-kujut-kunstis, lk 2-5).

Kunstniku eesmärk oli tutvustada Kalevipoja kaudu oma rahvast, kodumaad ja kultuuri, mida Nõukogude okupatsiooni tõttu maailmas ei tuntud. Neeme tegi põhjaliku eeltöö ning sai hea ülevaate ligi 60 kunstniku Kalevipoja-aineliste kujutava ja tarbekunsti teostest perioodil 1830-1961. Ta koostas lühikokkuvõtteid kunstnike töövõtetest ja loomemeetoditest, alustades Georg Friedrich Schlaterist, Friedrich Ludwig von Maydellist, August Weitzenbergist, Tõnis Grenzsteinist, Amandus Adamsonist, Oskar Hoffmannist ning analüüsis teiste hulgas ka Kristjan Raua, Oskar Kallise, Evald Okase, Peeter Ulase ja Eerik Haameri teoseid (G. Neeme erakogu: Kp-kujut-kunstis 1, lk 1-7). Temagi tõi esile Raua kui esimese

3 Autori vastavateemalistele mõtisklustele andis tuge ja kuju Kadri Tüüri e-kiri autorile, 03.06.2012. 
kunstniku, "kes ei illustreerinud vaid lõi kunstilise kompositsiooni Kalevipoja taustal ainetel” (G. Neeme erakogu: Kp-kujut-kunstis, lk 1).

Neeme hinnangul moodustas "eri peatüki" esimese ja teise Vene okupatsiooni ajal loodud Kalevipoja-ainestik ning ta selgitas, et kõigepealt tuleb mõista nende Eesti kunstnike olukorda ja tingimusi, milles nad pidi looma ja töötama, sest "siis saame ka ehk aru, miks üks või teine väljendus viis ja vorm ei ole meile vastuvõetav ning annab venepärase võõra maigu asjale juurde.” Tema hinnangul on ka pagulaskunstnikest paljud kindlasti katsetanud Kalevipoja "aine kallal", kuid kõik on jäänud vaid raamatuillustratsiooni tasemele (G. Neeme erakogu: Kp-kujut-kunstis, lk 1-2).

Kunstnik soovis, et raamatu kujundus eristuks kõigist teistest raamatutest, tutvustaks Eesti omapära ja samal ajal oleks kunstiliselt huvitav ka laiemale rahvusvahelisele publikule: “[...] meie Kalevipoeg on hoopis erinev raamat, milles õieti peegeldub mitte üksi mälestus minevikust, vaid ka meie esivanemate mõtteilm ja arusaam" (G. Neeme kiri Triinu Kartusele 28.07.2000, lk 12/1). Käsikirja kujunduses soovis ta kasutada eesti rahvapärase käsitöö mustreid (nt vöökirjad, vaibad jne), sest mustrid võimaldavad "mängida lehekülgede kavandamisega" ning "meie rahvamuster looks kaunistava meeleolu” (G. Neeme kiri Triinu Kartusele 15.11.1996, lk 2-3). Kunstnik koostas ja kujundas Kalevipoja käsikirja lehthaaval käsitsi küljendades, et kaalutletult katsetada, kuidas täpselt peaksid asetuma erisugused kujunduselemendid ning loogiliselt paigutuma eesti- ja ingliskeelsed tekstid.

Neeme lähtus väljaandele loodud kompositsioonides eepose teksti värsiridade rütmist, sisust ning tema kujutlusis tekkivatest muistsetest maastikest. Laak rõhutab, et tegu polegi algselt illustratsioonidega raamatule, vaid eepose värsiridade "tõlgetega" pildikeelde (Laak 2011: 13). Professionaalse kunstnikuna püüdis Neeme samastuda müüdi esitaja nägemis- ja kujutamisoskusega. Ta põhjendas, et professionaalne kunst oli külakogukonnas elanud eestlastele uus ja lühiajaline nähtus, mistõttu muster ja sõna kuuluvad rahvalikult rohkem omavahel kokku kui "alles 18. sajandi 
keskpaiku meie rahvale varasemalt tundmatu pildiline joonistus inimesest" (G. Neeme kiri Triinu Kartusele, 15.11.1996, lk 2).

On tähelepanuväärne, et Pallase kunstikoolis õppinud ning II maailmasõja ajal Saksamaale ja seejärel Austraaliasse emigreerunud kunstnik tegi esimesi Kalevipoja-ainelisi katsetusi juba Pallase-päevil, hiljem ka Saksamaal ja Austraalias. Need katsetused piirdusid tema sõnul "tugeva poisi - hiidliku kangelase kujutamisega"

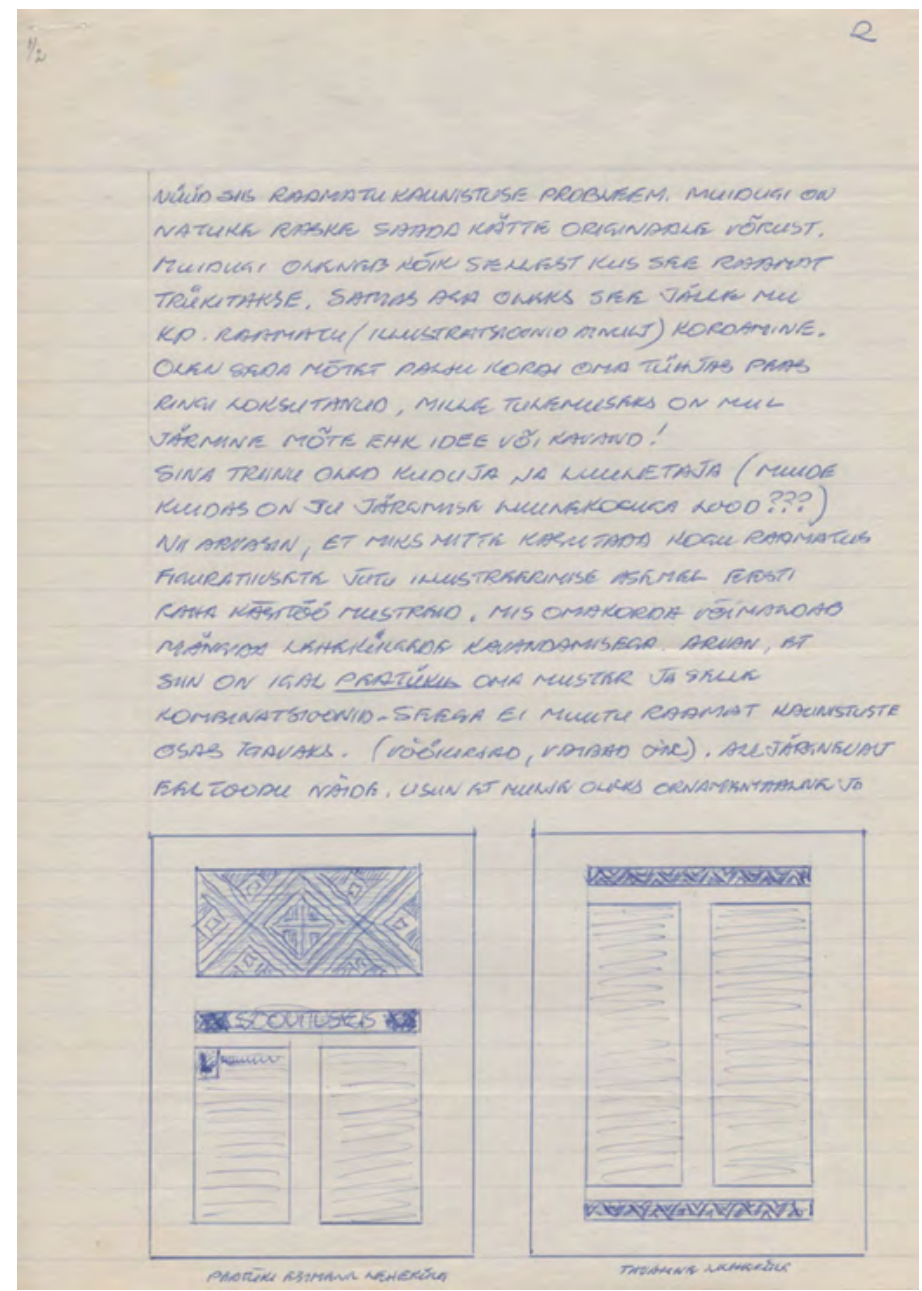

Gunnar Neeme "Kalevipoja" maketi-visandite näiteid: esialgne nägemus kogu teosest. 
ning aja jooksul muutus see üliinimene tema teostes igapäevaseks ja reaalseks inimeseks. Ta kirjutas: "Viimased viis-kuus aastat on aga olnud minus kahtlus, et midagi on viltu - midagi pole nagu õige. Kõik on nagu varemloodu kordamine" (G. Neeme erakogu: Kp-kujut-kunstis, lk 4). Ta soovis leida uusi vaatenurki ja võimalusi, kuidas Kalevipoega kujutada.

Neeme püüdis hoiduda eepose teemade illustreerimisest ning "astuda üks samm edasi": "Ja nii hakkasin ma kaaluma ja sõeluma mõtet, et Kalevipojale lähenemine võiks olla hoopis erinev senistest seisukohtadest. Ja see on eestlases aastatuhandeid asunud alateadvuslik tunne, mis andis põhjuse Kalevipojas esitatud sündmuste kujundamisele: abstraktne sümbolism, alateadvuses pesitsev mana. Kuna ma juba varem mainisin et kogu loos pole tegelikult tegemist mitte ühe inimesega, vaid kogu rahvaga, nii ei esita ma mitte kangelast ja tema tegusid, vaid kogu meie rahvast ja [soovin] luua tunde maailma... st mitte illustreerida, vaid tõlkida" (G. Neeme erakogu: Kp-kujut-kunstis, lk 5).

Pika eeltöö tulemusel otsustas ta, et tuleb "välja tuua "Kalevipoja" vaim, see alateadvusest rahva mõte. Meie tunde maailma. On üsna loomulik, et ühel või teisel juhul pean lisama ka Kalevipoja kui figuuri, kuid see pole "Kalevipoeg" ise, vaid sümboolne määritlus. Senini on seda saavutanud ja teinud ainult Kr. Raud. Tema primitiivselt ürgjõulisus on minule võõras. Teatud momentidel isegi [väga] võõras. Seepärast olen jäänud peatuma nn subconcious halfdream väljendi juurde" (G. Neeme erakogu: Kp-kujut-kunstis, $1 \mathrm{k} 6)$.

Alateadlikel tunnetus- ja une-aja tasanditel "Kalevipoja" müüditegelikkuse kujutamine äratas kunstnikus meeleolusid, mis olid seotud ka kaugel asuva kodumaaga. Neeme kirjutas Kartusele: "Mis aga puutub "Kalevipoja" piltide kohta, siis pean seda väga tõsiselt arutama. Sest paljud neist ei seleta/kujuta lugusid või sündmusi, vaid tõlgivad pildilikult sündmust, seega rõhutavad pildiliselt meeleolu. Nagu pildid vanast eesti talust, inimestest, jne. samuti ka meie usust, arusaamast ning probleemidest" (G. Neeme kiri Triinu Kartusele 28.07.2000, lk 12/1-2). 

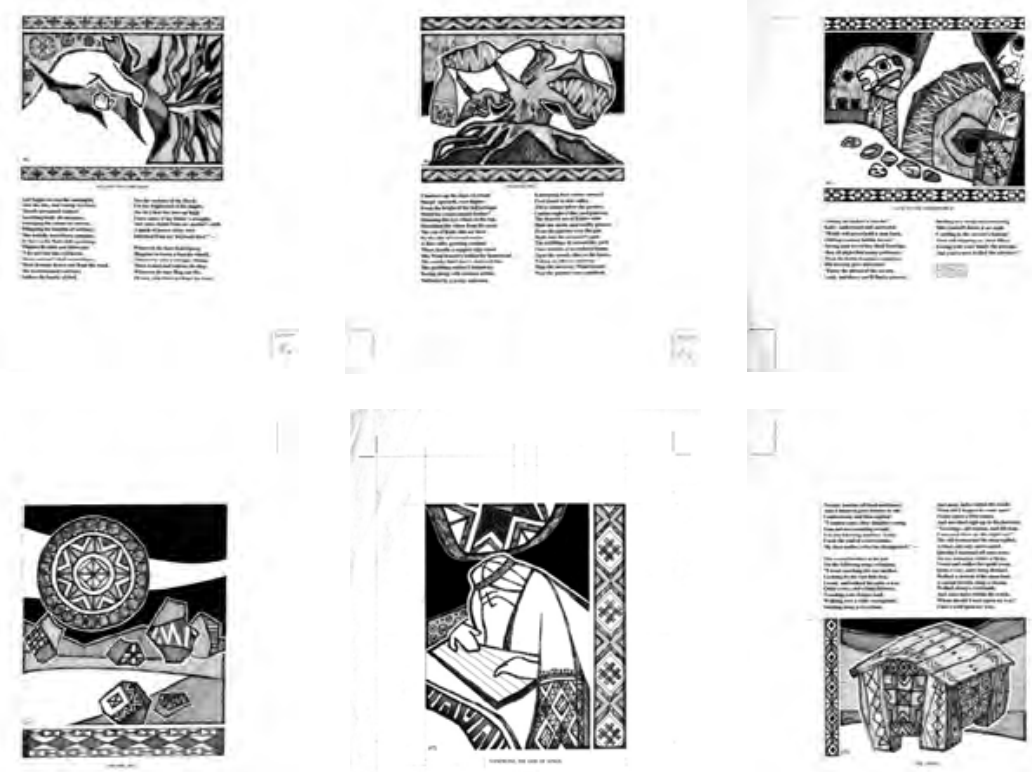

Gunnar Neeme "Kalevipoja” maketi näiteid illustratsioonidega: Tuuslari tapmine, suur tamm, Allilma värav, taevas, Vanemuine, kirst.

Kalevipoja värsiridade lugemisel loodud kompositsioone ja müüdimaastikke kujutades meenusid kunstnikule tema lapsepõlve kodumaa maastikud. Ta kirjutas Kartusele: "Olen kindel, et sinu töö juures, vaatamata tõlke probleemidele, viivad KP lood ja loogika tahtmatult Kodu Eesti radadele. Ja kas pole huvitav, et ka minu väikeses osalemises on Austraalia unustatud. Tulevad meelde päevad maal vanaema või onu juures. Otsekui loeksin neid heina kõrsi ja ajan juttu lehmade ning lammastega ja muidugi koertega. Peajoones aga naudin rehealuse ning küüni hõngu ning metsade salapärast, ent nii omast meeleolu. Eriti veel minule kui linnapoisile. Need on pildid ja tunnetused, millised minus kunagi ei unune ning nüüd siin Austraalias uuesti elama hakkavad" (G. Neeme kiri Triinu Kartusele 28.07.2000, 1k 12/1). Kirjadest selgub, et "Kalevipoja" käsikirja kujundamine andis autorile võimaluse ka unistada 

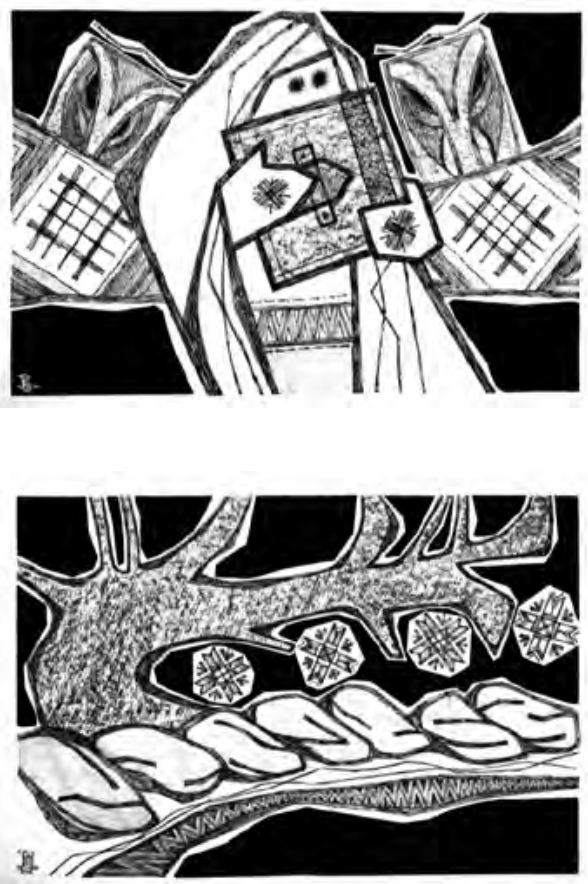

Gunnar Neeme loomingulist kreedot "mitte illustreerida, vaid tõlkida" kandvad pildid märkide ja vöökirjadega (vt Neeme, Kp-kujut-kunstis, lk 5). "Piiga" ja "Tamm".

ning piltlikult väljendades luua vaimne sild kodumaa ja lapsepõlve maastikega.

"Kalevipoja" kompositsioonides positsioneeris kunstnik end muistse lauliku ja mustrilooja kaasaega, püüdes näha ja esitada müuti tolleaegse looja kujutlusvõime ja teadmiste valguses. Neeme loodud figuraalsed kompositsioonid on erineva üldistusastmega, ta on neis teadlikult loobunud professionaalses kunstihariduses omandatud kujutusvõtetest: "Ühte peab kõigejuures arvestama, on see, et tolleaegne inimene nägi ja mõistis uusi ning ebatavalisi sündmusi ja asju teisiti, kui seda teeb isegi tavaline inimene tänapäeval” (G. Neeme kiri Triinu Kartusele 28.08.1997, lk 9/2). Neeme rõhutas, et Kalevipoja lugu on minevikus toimunud sündmustele rajatud mälestused ning meie rahva hinge peegeldused, meie hing ja arusaam (G. Neeme kiri Triinu Kartusele 28.07.2000, lk 12/1). Kunstnik lähtub "Kalevipoja” kujundamisel üldistatud ja ornamenteeritud figuurist kui märgist, sümbolist ja mustrist, püüdes 


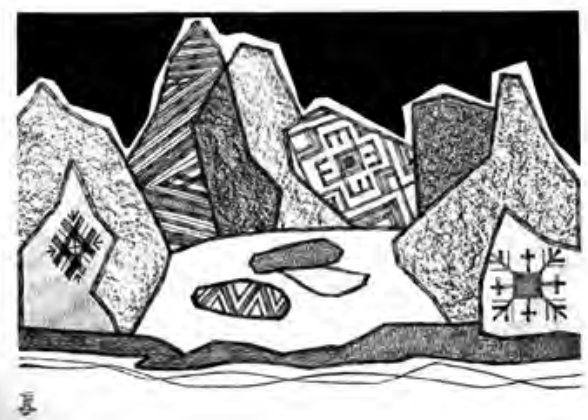

"Muinasmaastik" ja

"Muinastaevas".

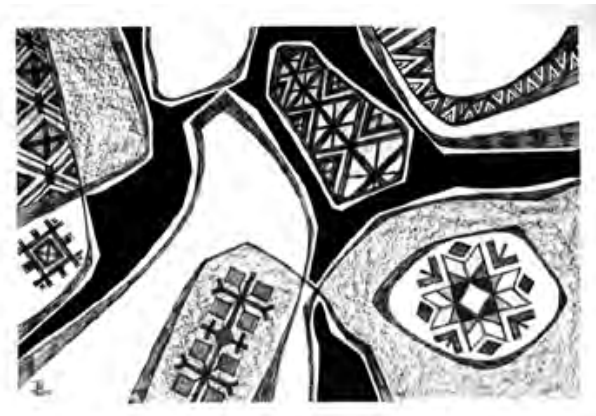

samastuda muistses ja arhailises kunstiruumis või külakogukonnas üles kasvanud loojaga, kes talletab ja esitab oma tundeid ning hinges toimuvaid elamusi ja kogemusi suulise või ainelise rahvaloomingu kaudu.

Tutvudes kunstniku loodud algse "Kalevipoja" käsikirjaga, selgub, et Neeme kujunduskontseptsiooni ning käsikirjalist autoriraamatut, mis on "täiesti erinev kõigist senistest" (G. Neeme kiri Triinu Kartusele, 15.11.1996, lk 2), on eepose 150. juubeliaastal (2011) ilmunud väljaande kujunduse ja trükimaketi autorid põhjalikult muutnud. Neeme käsikirjas on tekstis, päises ja peatükkide vahelehtedel asuvate kompositsioonide ülal, all või külgedel stiliseeritud mustrijoonised, mille otstarvet kunstnik põhjendas järgmiselt: "Igal peatükil peaks olema oma vöökirja või vaiba muster ja selle kombinatsioonid, et raamat ei muutuks igavaks. Usun et mulje oleks ornamentaalne ja puhas" (G. Neeme kiri Triinu Kartusele, 15.11.1996, lk 2). Trükis ilmunud väljaandes need ornamendid aga 

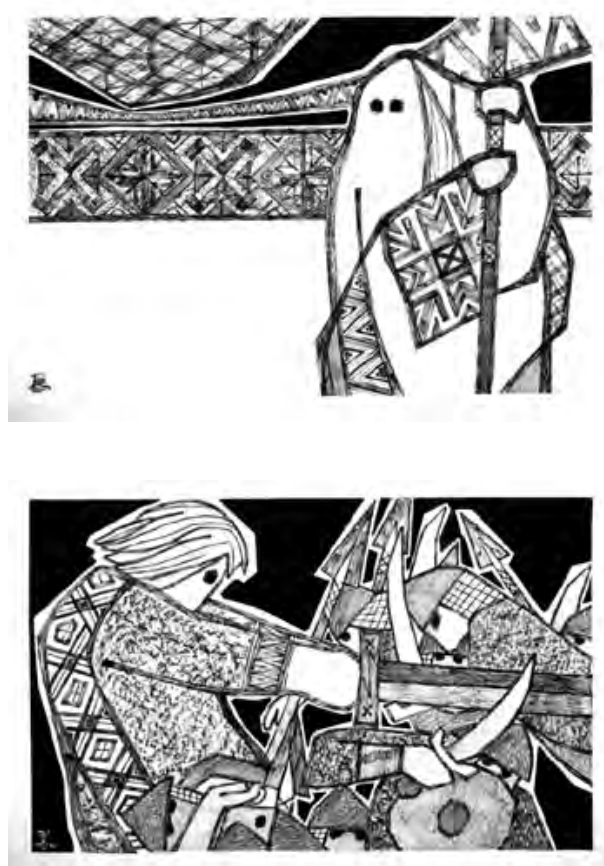

"Vana" ja

"Võitlus".

puuduvad, sest Eesti Kirjandusmuuseumi ning kirjastuse "Kunst" koostöös sündinud kujunduses on Neeme algsest kujundusideest ja sõnumist loobutud.

Siinkohal kerkib küsimus, milliseid väärtuslikke visuaalsel kujul esitatud sõnumeid, elamusi ja tunnetusvälju kaotab kunstniku kujutlusis sündinud "Kalevipoeg" - "tõlge" ja müüdi taasesitus siis, kui autori poolt teadlikult või intuitiivselt valitud loomismeetodi nüanssidest ning kunstiruumi kuuluvast terviklahendusest väljaande avaldamisel loobutakse. Kas kunstniku visioon ja sõnum muutuvad ning moonduvad või püsivad samana? Kas selline moonutatud teos on vaatajale vastuvõetavam ja "tänapäevasem" või on midagi väärtuslikku mentaalsel tasandil kaduma läinud? Miks autori poolt teadlikult loodud tervikteos taandatakse teksti kaunistavate dekoratiivsete illustratsioonide-stilisatsioonide tasemele? Kuidas suure töömahu ja süvenemisastmega loodud tervikteose autor, kelle kunstiline sõnum "tükeldatakse", võiks sellise tulemusega rahul olla? Siinkohal tasub võrdluseks meenutada ka Raua 
mitmetähenduslikku ja sügava tunnetusega loodud teoste kogumit, mis "Kalevipojas" ilmus kunstipubliku kätte samuti fragmentaarsena, illustratsioonide tasemele taandatuna.

\section{Kokkuvõtteks}

Kreutzwaldi "Kalevipojaga" kõrvuti eksisteerib Eesti kunstis mitmeid kunstnike "Kalevipoegi", mille loomisel on teoste autorid lähtunud nii eepose tõlgendustest, tellija-vaataja harjumustest-ootustest, müüdi taasesitusega seotud mõtteeksperimentidest, isiklikest kogemustest või kunsti tunnetusjõu seostest kunstiruumi mitmetasandiliste tähendusväljadega. Kuna kunstnikud tavaliselt ei püüa ega soovi oma kujutlusvõime ja loomeprotsessi tagamaid analüüsida, veel vähem argikeele tasandil sõnastada, saab "Kalevipoja" väljaandeid uurides lähtuda eelkõige Eesti kunstihariduse ja professionaalse kunsti traditsioonidest.

Eepose väljaannetes ilmunud teostes on kunstnikud rahvaloomingu esemelist pärandit ja ornamente uurinud ning kujutanud erisuguse süvenemisastmega ja eri meetodeid kasutades. Tänapäeva kunstnikud, kellel on oma "käekiri" ja loojasõnum, enamasti ei uuri ega mõtesta minevikku, vaid keskenduvad nüüdisaegse inimese hingeelule, ühiskonna probleemidele ning üksikisiku vaevadele, rõõmudele ja muredele. Eepose ja müüdi teemadega kokku puutudes võivad loojad sellegipoolest väärtuslikke teoseid luua ning eepose tõlgendustraditsiooni seniseid piire lõhkudes ja uuendades tõlgendada eepost ka pelgalt lugemiskogemuse põhjal tänapäeva inimese isiklike elamuste, väärtushinnangute ja elukogemuse võtmes. Kuid järgmiste "Kalevipoja" väljaannete kujundamise puhul on oluline ka küsimus, kuidas põimida tänapäeva maailmas elava ja tegutseva kunstniku kujutlusvõimet ning kunstiruumi tunnetuslikke tasandeid müütide algupäraste ja arhailiste tunnetustavadega. 


\section{Allikad}

Kalevipoeg (1999). Eesti Muistendid. Hiiu- ja vägilasmuistendid I. Monumenta Estoniae Antiquae II. EKI folkloristika osakond, EKM Eesti Rahvaluule Arhiiv. Tallinn: Eesti Keele Instituut. Internetis http://www.folklore.ee/rl/folkte/myte/ kalev/failb.html (vaadatud 25.07.2012).

Kreutzwald, Friedrich Reinhold 1936. Kalevipoeg. Tartu: Eesti Kirjanduse Selts. Kreutzwald, Friedrich Reinhold 1946. Kalevipoeg. Tallinn: Ilukirjandus ja Kunst.

Kreutzwald, Friedrich Reinhold 1951. Kalevipoeg. Tallinn: Eesti Riiklik Kirjastus.

Kreutzwald, Friedrich Reinhold 1961. Kalevipoeg. Tallinn: Eesti Riiklik Kirjastus.

Kreutzwald, Friedrich Reinhold 1975. Kalevipoeg. Tallinn: Eesti Raamat.

Kreutzwald, Friedrich Reinhold 2009. Kalevipoeg. Tallinn: SE\&JS.

Kreutzwald, Friedrich Reinhold 2011. Kalevipoeg. Tartu-Tallinn: Eesti Kirjandusmuuseum, Kunst.

\section{Kirjandus}

Annist, August 1936. Viienda trüki saatesõna. - Kreutzwald, Friedrich Reinhold. Kalevipoeg. Tartu: Eesti Kirjanduse Selts, lk 285-290.

Biggs, Michael A. R. 2004. Learning from Experience: approaches to the experiential component of practice-based research. - Forskning, Reflektion, Utveckling. Ed. H. Karlsson. Stockholm: Vetenskapsrådet, Swedish Research Council, pp. 6-21.

$\mathrm{EE}=$ stilisatsioon. - Eesti Entsüklopeedia 8,1995. Tallinn: Eesti Entsüklopeediakirjastus.

ENE = illustratsioon. - Eesti Nõukogude Entsüklopeedia 3, 1988. Tallinn: Valgus. 
Eisen, Matthias Johann 1920. Kalevipoja esi-isad. Teine, täiendatud trükk. Tallinn: Eestimaa Kooliõpetajate Vastastikuse Abiandmise Seltsi Raamatukaupluse Kirjastus.

Eisen, Matthias Johann 1995. Eesti mütoloogia. Tallinn: Mats.

Eliade, Mircea 1974. Shamanism: Archaic Techniques of Ecstasy. Bollingen Series LXXVI, Princeton: Princeton University Press.

Gombrich, E. H. 1997. Kunsti lugu. Tallinn: Avita.

Hoppál, Mihály 2008. Etnosemiootika. Tartu: EKM teaduskirjastus.

Kalm, Mart 2010. Kujundades ja tootes. - Eesti kunsti ajalugu V, 1900-1940. Toim. Mart Kalm. Tallinn: Eesti Kunstiakadeemia Kirjastus, lk 583-602.

Kangro-Pool, Rasmus 1961. Kristjan Raud: 1865-1943. Tallinn: Eesti NSV Kunst.

Kirme, Kaalu 1999. Autoportree silmusega. Adamson-Ericu dokumentaalne eluromaan. Tallinn: Kunst.

Knuuttila, Seppo 2010. Nähdyt ja kuvannetut myytit. Preconcieving and visualizing myths. -Myytti, kuva, mielikuva. Myth, image, idea. Mito, imagen, idea. Kalevala granaína. Toim. Manuel Velés Cea, Annika Waenerberg. Jyväskylä-Granada: Mänty kustannus OY, s. 9-21.

Krull, Hasso 2006. Loomise mõnu ja kiri. Loomingu raamatukogu, 5/6. Tallinn: SA Kultuurileht.

Kuma, Helene 2001. Rahvakunsti traditsioon eesti tarbekunstis. Ajalooline tagasivaade. - Rahvatraditsioonidest eesti kunstis. Viljandi: Viljandi Kultuurikolledž, Talukujunduse ja rahvusliku käsitöö kateeder, Eesti Kunstiakadeemia tekstiilikunsti osakond, lk 21-27.

Kõiva, Mare 2010. Eestlased ja eesti keel Austraalias. - Eestlased ja eesti keel välismaal. Toim. Kristiina Praakli, Jüri Viikberg. Tallinn: Eesti Keele Sihtasutus, $1 \mathrm{k} 265-283$.

Laak, Marin 2011. Saateks. - Kreutzwald, Friedrich Reinhold. Kalevipoeg. The Estonian National Epic. Eesti rahvuseepos. Tartu-Tallinn: Eesti Kirjandusmuuseum, Kunst, lk 12-13.

Lang, Valter 1999. Kultuurimaastikku luues. Essee maastiku religioossest ja sümboliseeritud korraldusest. Eeati Arheoloogia Ajakiri, nr 3/1, lk 63-85. 
Laugaste, Eduard 1951. Järelsõna. - Kalevipoeg. Tallinn: Eesti Riiklik Kirjastus, lk 319-346.

Laugaste, Eduard; Normann, Erna 1959. Muistendid Kalevipojast. Eesti muistendid. Hiiu- ja vägilasmuistendid I. Monumenta Estoniae Antiquae II. Tartu Riiklik Ülikool, Eesti NSV Teaduste Akadeemia, Fr. R. Kreutzwaldi nimeline Kirjandusmuuseum. Tallinn: Eesti Riiklik Kirjastus.

Levin, Mai 2010. Rahvusromantism eesti kunstis. - Eesti kunsti ajalugu V, 1900-1940. Toim. Mart Kalm. Tallinn: Eesti Kunstiakadeemia Kirjastus, lk 97-127.

Lévi-Strauss, Claude 2001. Metsik mõtlemine. Tallinn: Vagabund.

Lotman, Juri 1999. Semiosfäärist. Tallinn: Vagabund.

Lotman, Juri 2001. Kultuur ja plahvatus. Tallinn: Varrak.

Lönnrot, Elias 1939. Kalevala. Tartu: Eesti Kirjanduse Selts.

Niedderer, Kristina; Imani, Yassaman 2008. Developing a Framework for Managing Tacit Knowledge in Research using Knowledge Management Models. - Undisciplined! Proceedings of the Design Research Society Conference 2008. Sheffield: Sheffield Hallam University. Internetis http://shura.shu.ac.uk/507/1/ fulltext.pdf (vaadatud 02.07.2012).

Nirk, Endel 1975. Eesti rahvuseepos "Kalevipoeg". - Kreutzwald, Friedrich Reinhold. Kalevipoeg. Tallinn: Eesti Raamat, lk 263-274.

Nonaka et al. 2000 = Nonaka, Ikujiro; Toyama, Ryoko; Konno, Noboru. SECI, ba, and leadership: a unified model of dynamic knowledge creation. - Long Range Planning, 33: 1, pp. 5-34.

Polanyi, Michael 1962. Personal Knowledge: Towards a Post-Critical Philosophy. Chicago: University of Chicago Press.

Põllu, Kaljo 1990. Tallinna Kunstiülikooli kümme soome-ugri uurimisreisi. Tallinn: Olion.

Põllu, Kaljo 1999. Eesti Kunstiakadeemia kakskümmend soome-ugri uurimisreisi. Tallinn: Olion.

Päts, Voldemar 1928. Riigi Kunsttööstuskooli ópilaste tööd. Tallinn: Riigi Kunsttööstuskool.

Raud, Eno 1961. Kalevipoeg. Tallinn: Eesti Riiklik Kirjastus. 
Raud, Eno 1976. Kalevipoeg. Tallinn: Eesti Raamat.

Raud, Eno 1998. Kalevipoeg. Tallinn: Tiritamm. Internetis http://www.nlib.ee/ html/digi/rmt_ill/autorid/tammsaar_j/tam_kalev.html (vaadatud 14.02.2012).

Raud, Kristjan 1911. Oli ennemuiste nõnda - Eesti Kultura I, lk 351-355.

Raud, Kristjan 1913. Kas kasvame või kaome = Mõtted rahvakunstitööde korjamise puhul. - Eesti Rahva Muuseum, lk 3-5.

Raunam, Oskar 1964. Õppeasutuse rajamise ja arengu ajaloost. - Eesti NSV Riiklik Kunstiinstituut. 50 aastat kunstialast haridust. Tallinn: Eesti NSV Kunst, lk 7-23.

Scrivener, Stephen A. R. 2006. Visual Art Practice Reconsidered: Transformational Practice and the Academy. - The Art of Research. Research Practices in Art and Design. Eds. M. Mäkelä, S. Routarinne. Helsingi: Publication Series of the University of Art and Design Helsinki A 73, pp. 157-179.

Schön, Donald A. 1983. The reflective practitioner: How professionals think in action. New York: Basic books.

Sibrits, Heili 2009. Tegin. Sest tahtsin. - Postimees, 07.11.2009. Internetis http:// pluss.postimees.ee/184870/tegin-sest-tahtsin/ (vaadatud 14.02.2012).

Siikala, Anna-Leena 2002. Mythic Images and Shamanism. A Perspective on Kalevala Poetry. FFC 280. Helsinki: Suomalainen Tiedeakatemia.

Summatavet, Kärt 2007. Mõningaid mõtteid kunstist, Kristjan Rauast ja vanavara kogumisest. - Mäetagused nr 37, lk 7-44.

Summatavet, Kärt 2010a. Rahvaesteetika - nähtavaks kujustatud mõte ja kogemus. - Mäetagused nr 44, lk 7-28.

Summatavet, Kärt 2010b. Myytti ja mielikuvitus. Mythology and artist's imagination. - Myytti, kuva, mielikuva. Myth, image, idea. Mito, imagen, idea. Kalevala granaína. Toim. Manuel Velés Cea, Annika Waenerberg. Jyväskylä-Granada: Mänty kustannus OY, s. 23-37.

Summatavet, Kärt 2011. "Suured müstilised muinaslilled" hinges ja loometöös. - Lee. ERMi Sõprade Seltsi aastaraamat 17. Toim. T. Sikka, S. Madisson, T. Kaalep, lk 34-39.

Sõgel et al. 1953 = Sõgel, E.; Izmestjev, P. N.; Kangilaski, O.; Lepik, M.; Raud, L.; Tobias, H.. Fr. R. Kreutzwald 1803-1882. Elu ja tegevus sõnas ja pildis. Eesti NSV Teaduste Akadeemia Kirjandusmuuseum. Tallinn: Eesti Riiklik Kirjastus. 
Tralla, Johannes 2009. Ilmus uute illustratsioonidega "Kalevipoeg" - ERR, 05.11.2009. Internetis http://uudised.err.ee/index.php?06183677.

Urgart, Oskar 1946. Saateks. - Kreutzwald, Friedrich Reinhold. Kalevipoeg. Tallinn: Ilukirjandus ja Kunst, lk 235-237.

Valk, Ülo 2011. "Kalevipoja” lauliku maailm: loomisest, eeposest ja müüdist. Kreutzwald, Friedrich Reinhold. Kalevipoeg. The Estonian National Epic. Eesti rahvuseepos. Tartu-Tallinn: Eesti Kirjandusmuuseum, Kunst, lk 532-535.

Vélez Cea, Manuel; Waenerberg, Annika 2010. Prologi. Prologue. - Myytti, kuva, mielikuva. Myth, image, idea. Mito, imagen, idea. Kalevala granaina. Toim. Manuel Velés Cea, Annika Waenerberg. Jyväskylä-Granada: Mänty kustannus OY, s. 5-7.

Vélez Cea, Manuel; Waenerberg, Annika 2010. Kalevala granaína. Myyttejä, kuvia ja tulkintoja. Kalevala granaína. Myths, images and interpretations. Mytti, kuva, mielikuva. Myth, image, idea. Mito, imagen, idea. Kalevala granaína. Toim. Manuel Velés Cea, Annika Waenerberg. Jyväskylä-Granada: Mänty kustannus OY, s. 121-178.

Vetemaa, Enn 1985. Kalevipoja mälestused. Tallinn: Eesti Raamat. Internetis http://www.kirmus.ee/Asutus/Arrak2.php (vaadatud 14.02.2012).

\section{Internetiallikad}

Tali, Andres 2003. Iha ja igatsuse instrumendid - Mängi minuga. Internetis http://www.estpak.ee/ atali/instruments/instruments.html (vaadatud 14.02.2012).

Tali, Andres 2004. Iha ja igatsuse instrumendid ...Sick and Tired... Internetis http://www.estpak.ee/ atali/instruments/instruments.html (vaadatud 14.02.2012).

Tali, Andres 2006. 11 stilli/11 stills. Internetis http://www.estpak.ee/ atali/ instruments/stills.html (vaadatud 14.02.2012). 


\section{Käsikirjalised allikad}

G. Neeme käsikiri Friedrich Reinhold Kreutzwaldi "Kalevipoeg”, eesti- ja ingliskeelne tõlge ja kujundus.

G. Neeme käsikiri "Kp-kujut-kunstis 1".

G. Neeme käsikiri "Kp-kujut-kunstis”.

G. Neeme kiri Triinu Kartusele 15.11.1996.

G. Neeme kiri Triinu Kartusele 28.08.1997.

G. Neeme kiri Triinu Kartusele 28.07.2000.

K. Tüüri e-kiri K. Summatavetile 03.06.2012.

\section{Summary}

\section{Artist's Kalevipoeg: the artistic representations of epic and myth from Kristjan Raud to Gunnar Neeme}

The article focuses on the analysis of the artistic works that represent mythical and epical subject matter on the example of the illustrations incluced in the publications of the Estonian national epic "Kalevipoeg". Three methods can be distinguished that different artists have employed in representing the mythical characters and events in the case of different issues of the epic: illustration and stilisation, delivering artistic message, and engaging in a creation story. Epic and myth can be regarded as the results of human imagination. In their artistic interpretation, vernacular and professional art intermingle, as well as addressing global and personal, eternal and temporal themes. The role of an artist as the intermediator in representing the myth and the artist's role as an interpreter of the folklore is addressed, as well as the ethical and aesthetical ques- 
tions that raise in the course of interpretation. The phenomeonon of artistic research is also discussed in association with the artist's aspirations to elaborate the grounds for his interpretation.

Key words: Myth, epic, art, Kalevipoeg, method of creation, phantasy, inspiration, representations of a myth 